\title{
A STUDY ON THE UTILIZATION OF THE EXOTIC INVASIVE SPECIES HYPOCHAERIS RADICATA L. AS MANAGEMENT PERSPECTIVE
}

\author{
Hwang, H. J. ${ }^{1 \#}-$ LeE, M. ${ }^{1 \#}-$ KIM, J. H. ${ }^{1}-$ LEE, S. ${ }^{1}-$ SON, D. ${ }^{2}-$ OH, J. M. ${ }^{1}-$ SONG, U. ${ }^{1,2^{*}}$ \\ ${ }^{I}$ Department of Biology, Jeju National University, Jeju 63243, Republic of Korea \\ ${ }^{2}$ Research Institute for Basic Sciences, Jeju National University, Jeju 63243, Republic of Korea \\ *Corresponding author \\ e-mail:uhrami@gmail.com; phone: +82-64-754-3525; fax: +82-64-756-3541
}

\#These authors contributed equally to this work (co-first authors)

(Received $1^{\text {st }}$ Feb 2019 ; accepted $21^{\text {st }}$ Mar 2019)

\begin{abstract}
Although Hypochaeris radicata L. is a noxious alien species in Korea, there is no effective way to prevent it from spreading. Therefore, this study aims to study the possibility of using H. radicata as an effective natural compound source which will contribute to the utilization of the invasive alien species and some extent to prevent invasion. Hot water and ethanol extracts of $H$. radicata showed high efficiency as a natural antioxidant indicating the species may be used as a natural antioxidant material. Extracts of $H$. radicata has shown no toxic effects on cells. Rather, $H$. radicata extract has an function of inhibiting the generation of $\mathrm{NO}$ in high concentrations of extracts which means that $H$. radicata extract has a function of anti-inflammatory effect. When the research on the effect of $H$. radicata finds out more, the utilization of this species will be increased and the environmentally friendly public participation management will be possible due to an increase in its collection. Also, it is meaningful that we have attempted to find an ecological engineering approach through utilization methods of alien species that has been spread widely in Korea.
\end{abstract}

Keywords: cat's-ear, natural compounds, antioxidant, anti-inflammatory, alien species

\section{Introduction}

Invasive alien plants are species that are dispersed outside their original habitats through intentional or unintentional means, which can harm the environment. This destruction will result in loss of ecosystem function and extinction of native species, eventually reducing biodiversity, ultimately resulting in socioeconomic decline (Samways et al., 1996). However, these exotic species can be used as sources of natural compound (medicine, cosmetic etc.), that such development of these uses may help to manage such exotic species through increase the harvest of this species in the wild (Maema et al., 2016), as a kind of ecological engineering. The free radical and properties containing natural antioxidants that metabolize the endogenous products of several oxidizing species are facilitated by ecological stress (Grassmann et al., 2002) for most plants, and studies of these natural products are useful for confirming the availability of plants. Recently, there has been an increasing interest in natural antioxidants, which can protect humans from damage caused by oxidative stress (Scalbert et al., 2005). This study attempts to approach Hypochaeris radicata L., which causes many problems in Jeju Island and some inland regions (Kim et al., 2006), as a new perspective. $H$. radicata is managed because it is designated as a harmful species in the Ministry of Environment. However, in Jeju Island, H. radicata is already the most dominant species. Thus, realistic removal and management of this species are difficult 
and showed no results so far (Ryu et al., 2017). From the discovery of $H$. radicata in Chungcheong and Jeolla, it shows that diffusion and settlement have already occurred inland (Hyun et al., 2018). Therefore, the case of $H$. radicata shows that there is a limitation in the existing management methods for general harmful species. Therefore, we investigated the medicinal efficacy of $H$. radicata through the view as a resource. Through this, the research applying the idea that increasing the use of these alien species is a positive management of alien species ( $\mathrm{Li}$ et al., 2015). For this purpose, we conducted a study on the efficacy of $H$. radicata.

\section{Materials and methods}

\section{Plant sampling}

In October 2018, 10 habitats from the northern part of Jeju island, Korea were randomly selected and the $H$. radicata used for the experiment were collected. Every sampling sites were unmanaged areas inside of agricultural fields, mostly close to roads. Sampling sites were relatively flat areas and dominated by $H$. radicata. The geographic coordinates of the center of the sampling sites are $33^{\circ} 27^{\prime} 49^{\prime \prime} \mathrm{N}, 126^{\circ} 29^{\prime} 07^{\prime \prime} \mathrm{E}$. Ten plant samples were collected from each site and used as one large sample. Harvested plants were washed and then dried for $24 \mathrm{~h}$. The stems and leaves except roots were cut into the crusher and used as experimental material.

\section{Total antioxidant capacity (TAC) the superoxide dismutase activity (SOD) using raw plant}

From plant leaves, crude extracts were prepared by re-suspending the frozen cells in $50 \mathrm{mM}$ phosphate buffer $(\mathrm{pH} 7.2)$. The plant samples $(0.1 \mathrm{~g})$ were washed and then the cells were quick-frozen in liquid $\mathrm{N}_{2}$ and milled subsequently. Phosphate buffer $(1 \mathrm{ml}$; Sigma-Aldrich Corp.) was added and the suspension was stirred using Vortex mixer. Waited more than $30 \mathrm{~min}$ for protein extraction. After centrifuging at $14,000 \mathrm{rpm}$ at $4{ }^{\circ} \mathrm{C}$ for $20 \mathrm{~min}, 400 \mu \mathrm{l}$ of the supernatant was collected for the experiments. Absorption was measured using SpectraMax (Molecular Devices, USA). Protein quantities were determined by using Bradford assay (Bradford, 1976) to obtain a standard curve. Total Antioxidant capacity was measured by the antioxidant activity of an organic liquid using bathocuproine (Jaramillo-Flores et al., 2003) with a slight modification of the protocol. Our method comprises the following steps. First, mix a sample of the liquid $(15 \mu \mathrm{l})$ with bathocuproine $(200 \mu \mathrm{M} ; 585 \mu \mathrm{l})$ and stir using Vortex mixer and Pour a predetermined quantity $(200 \mu \mathrm{l})$ of each of the samples into the wells of a multi-well plate. Then, Perform spectrophotometric measurements of the samples at $490 \mathrm{~nm}(\mathrm{~S} 1)$. Add a predetermined quantity (50 $\mu \mathrm{l})$ of copper sulfate solution to each well and incubate it at room temperature for $5 \mathrm{~min}$; terminate the reaction using ethylenediaminetetraacetic acid (EDTA). Then again, Perform the second round of spectrophotometric measurements at $490 \mathrm{~nm}$ (S2). Total Antioxidant Capacity is calculated as $\mathrm{TAC}=\mathrm{S} 2-\mathrm{S} 1(\mu \mathrm{M} / \mathrm{ml})$. Finally, convert units using the Bradford assay results $(\mu \mathrm{M} / \mathrm{mg})$. The superoxide dismutase activity was measured using the methods established by Peskin and Winterbourn (2000) and protocols of the WST assay by Donindo, Japan.. Using a WST-1 (2-(4-Iodophenyl)- 3-(4-nitrophenyl)-5-(2,4disulfophenyl)- 2H-tetrazolium, monosodium salt) solution (Dojindo, Japan) and an 
Enzyme Working Solution (Dojindo, Japan), SOD activities were calculated under the Dojindo's protocols.

\section{Extract preparation}

The dried aboveground plant parts (i.e., leaves and branches) were coarsely powdered by using an electric blender. $32.6 \mathrm{~g}$ of dried plant powder was then, a) extracted with 500 $\mathrm{ml}$ of $70 \%(\mathrm{v} / \mathrm{v})$ ethanol for $24 \mathrm{~h}(\mathrm{EtOH})$ or b) extracted with $500 \mathrm{ml}$ of $90{ }^{\circ} \mathrm{C}$ distilled water (HW: Hot Water) for $2 \mathrm{~h}$. Then extracted solutions were filtered (Whatman No.1), and then concentrated with a rotary evaporator. Then the solution was freeze-dried to make the final product as powder.

\section{Radical scavenging assay for testing antioxidant effects of extracts}

DPPH (1,1-diphenyl-2-picrylhydrazyl) radical scavenging activity of the $H$. radicata were measured by a method suggested by Blois (1958). $180 \mu \mathrm{L}$ of DPPH solution in $0.4 \mathrm{mM}$ in ethanol was mixed with $20 \mu \mathrm{L}$ of the extract (DW and ethanol) and incubated in the dark at $25^{\circ} \mathrm{C}$ for $10 \mathrm{~min}$. Then, the absorbance of the sample (A sample) and negative control (A control) consisting of only ethanol alone was measured at $517 \mathrm{~nm}$. The DPPH radical scavenging activity of the sample was calculated by using Equation 1.

$$
\text { Scavenging activity }(\%)=100 \times \frac{(\text { A sontrol - A zample })}{\text { A control }}
$$

ABTS (2,2'-azino-bis-(3-ethylbenzothiazoline-6-sulphonicacid)) radical scavenging activity of the subtropical plant extracts was measured as a method by Zhu et al. (2011). ABTS and potassium persulfate solutions ( 7 and $2.45 \mathrm{mM}$, respectively) were mixed and then incubated in the dark at $25^{\circ} \mathrm{C}$ for $16 \mathrm{~h}$. The ABTS solution was diluted with ethanol to obtain the working solution with an absorbance at $745 \mathrm{~nm}$. Then, $20-\mu \mathrm{L}$ aliquots of the plant extract samples were dissolved in ethanol at different concentrations $(10-500$ $\mu \mathrm{g} / \mathrm{mL}$ ), mixed with $180 \mu \mathrm{L}$ of the working solution, incubated in the dark at $25^{\circ} \mathrm{C}$ for 10 min, and then the Abs sample and Abs control (ethanol only) were measured. The ABTS radical scavenging activity was calculated by using Equation 1.

\section{High performance liquid chromatography (HPLC)}

High Performance Liquid Chromatography (HPLC) was analyzed at NICEM (Seoul National University, South Korea) using Ultimate 3000 model, (Thermo Fisher Scientific, Waltham, MA USA). The flow rate was $0.8 \mathrm{~mL} / \mathrm{min}$ and the gradient was given using Buffer A [0.3\% trifluoroacetic acid (TFA)] and Buffer B (Acetonitrile). C-18 column $(4.6 * 250,5 \mathrm{um})$ was used and wavelength of $280 \mathrm{~nm}$ [190-800 nm diode array detection (DAD) scanning] was used for analysis. 12 standards that often used for phenolic compounds were used to detect natural compounds of $H$. radicata (syringic acid, salicylic acid, $p$-coumaric acid 4, ferulic acid, naringin, myricetin, hesperidin, trans-cinnamic acid, quercetin, naringenin, confertin, scopoletin).

\section{Cell culture}

Murine RAW 264.7 macrophages were obtained from the Korean Cell Line Bank (Seoul, South Korea). Cells were cultured in Dulbecco's modified Eagle's medium, supplemented with $10 \%$ fetal bovine serum, penicillin, and streptomycin sulfate (all from 
GIBCO, Grand Island, NY, USA), in an incubator at $37^{\circ} \mathrm{C}$ in a humidified atmosphere of $95 \%$ air and $5 \% \mathrm{CO}_{2}$. For this study the cells were mechanically passaged by dissociation every other day; they underwent fewer than 25 passages.

\section{Toxicity of plant extract (MTT assay)}

A 3-(4,5-dimethylthiazol-2-yl)-2,5-diphenyltetrazolium bromide (MTT) assay was undertaken as described previously by Yang et al. (2013). Cells were counted with a haemocytometer, and the number of viable cells was assessed by trypan blue dye exclusion method. The RAW 264.7 macrophages were seeded in 24-well plates for $18 \mathrm{~h}$ and then stimulated with various treatments $(250,500,1000,1500 \mathrm{ug} / \mathrm{mL}$ of $\mathrm{HW}$ and $50,100,200,500 \mathrm{ug} / \mathrm{mL}$ of $70 \% \mathrm{EtOH})$ or LPS (lipopolysaccharide) $(1 \mu \mathrm{g} / \mathrm{mL})$ for $1 \mathrm{~h}$. On the day of collection, cells were incubated with MTT solution for $24 \mathrm{~h}$ at $37^{\circ} \mathrm{C}$ in a humidified atmosphere of $95 \%$ air and $5 \% \mathrm{CO}_{2}$. The MTT-containing supernatant was removed and the formazan crystals were solubilized in dimethylsulfoxide. The absorbance of each well at $540 \mathrm{~nm}$ was measured using an automatic microplate reader (PowerWave X340, Bio-tech Instruments, Inc., Winooski, VT, USA).

\section{NO (nitric oxide) concentration as indicator of anti-inflammatory effects}

The NO concentration in treatments was determined based on the method of Yang et al. (2013). RAW 264.7 cells $\left(5 \times 10^{5}\right.$ cells/well) were cultured on 24 -well dishes with $1 \mu \mathrm{g} / \mathrm{mL}$ of LPS and various treatments $(250,500,1000,1500 \mu \mathrm{g} / \mathrm{mL}$ of HW and 50 , $100,200,500 \mu \mathrm{g} / \mathrm{mL}$ of $70 \% \mathrm{EtOH})$. After $18 \mathrm{~h}$, culture supernatants were collected and nitrite, a stable oxidized product of NO, was measured by a modified Griess (1879) method. Equal volumes $(100 \mu \mathrm{L})$ of the Griess (1879). Reagent [1\% sulfanilamide and $0.1 \% N$-(1-naphthyl)-ethylenediamine dihydrochloride in 5\% phosphoric acid] and $D$. divaricate, D. prolifera, P. cornea, G. lanceolata, or G. filicina were incubated together at room temperature for $10 \mathrm{~min}$. The absorbance of each well at $540 \mathrm{~nm}$ was measured using an automatic microplate reader (PowerWave X340, Bio-tech Instruments).

\section{Statistical analysis}

Differences between multiple groups were evaluated using oneway PROC analysis of variance (ANOVA). When a significant treatment effect was detected, post hoc comparisons of the means were performed using Tukey's honest significant difference test (SAS v. 9.1, SAS Institute Inc., USA). Differences were considered significant if $\mathrm{p}<0.05$.

\section{Results and discussion}

\section{Total antioxidant capacity (TAC) and superoxide dismutase activity (SOD)}

TAC and SOD were measured using fresh plant leaves instead of extracts (Table 1). To see the functions of the plant itself as a medicinal herb not the effects of extracts, TAC and SOD were selected. However, most other TAC studies of leaves of plants, results are re-directed to extracts by calculation, so it is difficult to make a direct comparison because the unit is L (liter). Rarely, among the existing studies using the same method as we did, there are results of Brassica campestris ssp. napus var. nippooleifera Makina (oilseed rape) and Lactuca sativa L. (lettuce), a leap-eating crop (Song 
et al., 2013). $H$. radicata is expected to have higher efficacy than conventional plants because it shows a high value of three times higher than that of this crop. In addition, the result can have the meaning of the archive showing the antioxidant value of the fresh leaf of $H$. radicata. In the case of SOD, it was possible to make a direct comparison with other papers since it came out as a unit. In the case of overseas studies using the same Dojindo SOD kit for medicinal herbs (Rafat et al., 2010), five herbicides showed an average value of about 60 unit (SOD unit). On the other hand, $H$. radicata has a value of 90 or more. Therefore, the antioxidant effect of $H$. radicata is expected to be high and gave us expectation for noticeable efficacy.

Table 1. Total antioxidant capacity and superoxide dismutase activity of $H$. radicata

\begin{tabular}{c|c}
\hline Sample & Value \\
\hline TAC $(\mu \mathrm{M} / \mathrm{mg}$ protein $)$ & $389.35 \pm 41.34$ \\
SOD $(\mathrm{U} / \mathrm{mg}$ protein $)$ & $94.03 \pm 2.21$ \\
\hline
\end{tabular}

Each value represents mean \pm S. D. $(n=4)$

\section{Radical scavenging assay for testing antioxidant effects of extracts}

Free radicals are known to cause various diseases by causing oxidative stress in the body. Therefore, DPPH and ABTS radical scavenging activities were measured to confirm the free radical inhibitory activity of $\mathrm{HW}$ extract and $70 \% \mathrm{EtOH}$ extract on the aboveground part of $H$. radicata. As a result, the DPPH radical scavenging activity of EtOH extract $($ IC50 $=139.63 \pm 5.30 \mu \mathrm{g} / \mathrm{mL}$ ) was higher than that of $\mathrm{HW}$ extract (IC50 $=167.91 \pm 3.94 \mu \mathrm{g} / \mathrm{mL}$ ) (Table 2). In the ABTS radical scavenging activity, HW extract $(\mathrm{IC} 50=58393 \pm 13.31 \mu \mathrm{g} / \mathrm{mL})$ was higher than EtOH extract $(\mathrm{IC} 50=155.94 \pm$ $35.27 \mu \mathrm{g} / \mathrm{mL}$ ) (Table 2). When DDPH radical scavenging activity of $H$. radicata was compared with other popular medicinal plants such as Trigonella foenum-graecum and Elettaria cardamomum (Khalaf et al., 2008). The IC50 value of $H$. radicata was lower. Therefore, it can be said that $H$. radicata showed higher efficiency as a natural antioxidant than popular medicinal plants (T. foenum-graecum and E. cardamomum). This suggests that $H$. radicata may be used as a natural antioxidant material. After conducting this experiment, we've found a new reference that has investigated DPPH and ABTS of $H$. radicata extract (Ko et al., 2017). This paper also showed that $H$. radicata extract has strong antioxidant effects, which is consistent with our results. However, our DPPH value of HW extract is low compared to other paper from a research group who have studied this plant steadily (Senguttuvan et al., 2014) while the local paper (Ko et al., 2017) showed similar value (EtOH) to our results. As Korea and India are very distant counties, ecotypes of $H$. radicata in India could be different. Also as climate condition of Korea is different from India (cold winter in Korea), it would affect the chemical composition of plants.

\section{Anti-inflammatory activity and toxicity of $\mathrm{HW}$ and EtOH extracts in $\mathrm{RAW} 264.7$ cells}

To determine the toxicity and anti-inflammatory effects of extracts, the most common method is to examine the cell viability by RAW 264.7 cells using NO production and MTT assay. In the HW extract, NO production was significantly increased in LPS only treatment (LPS +, Sample $0 \mu \mathrm{g} / \mathrm{mL}$ ) compared to control (LPS -, Sample $0 \mu \mathrm{g} / \mathrm{mL}$ ), but HW extracts treated with 500,1000 , and $1500 \mu \mathrm{g} / \mathrm{mL}$ showed 
that NO production decreased by concentration compared to LPS only treatment (Fig. 1). This shows that the higher the concentration, the stronger resistant the inflammation by NO product inhibition. Cell viability was also reduced in all treatments compared to control (LPS -, Sample $0 \mu \mathrm{g} / \mathrm{mL}$ ) and all values are lower than the value of LPS only treatment (LPS + , Sample $0 \mu \mathrm{g} / \mathrm{mL}$ ), but with the exception of $1500 \mu \mathrm{g} / \mathrm{mL}$ treatment. As the LPS itself is toxic, it is a normal response. However, when the extract is added, the toxicity is alleviated considering low values in most concentration range. In general, when the cell viability is $80 \%$ or more, it is considered that there is no problem, so that the overall extract, even including $1500 \mu \mathrm{g} / \mathrm{mL}$ treatment are safe to be considered as none toxic.

Table 2. Antioxidant activities of $H$. radicata extracts

\begin{tabular}{c|c|c}
\hline Sample & DPPH radical scavenging activity & ABTS radical scavenging activity \\
\hline $\mathrm{HW}$ & $167.91 \pm 3.94$ & $187.04 \pm 11.54$ \\
$\mathrm{EtOH}$ & $139.63 \pm 5.30$ & $203.6 \pm 4.68$ \\
Ascrobic acid & $6.48 \pm 0.25$ & $22.34 \pm 0.87$ \\
\hline
\end{tabular}

Each value represents mean \pm S. D. $(\mathrm{n}=4)$. IC50 $(\mathrm{IC} 50=\mu \mathrm{g} / \mathrm{mL})$ values were calculated from regression lines using eight different concentrations in triplicate experiments. HW; hot water extracts. EtOH; $70 \%$ ethanol extract

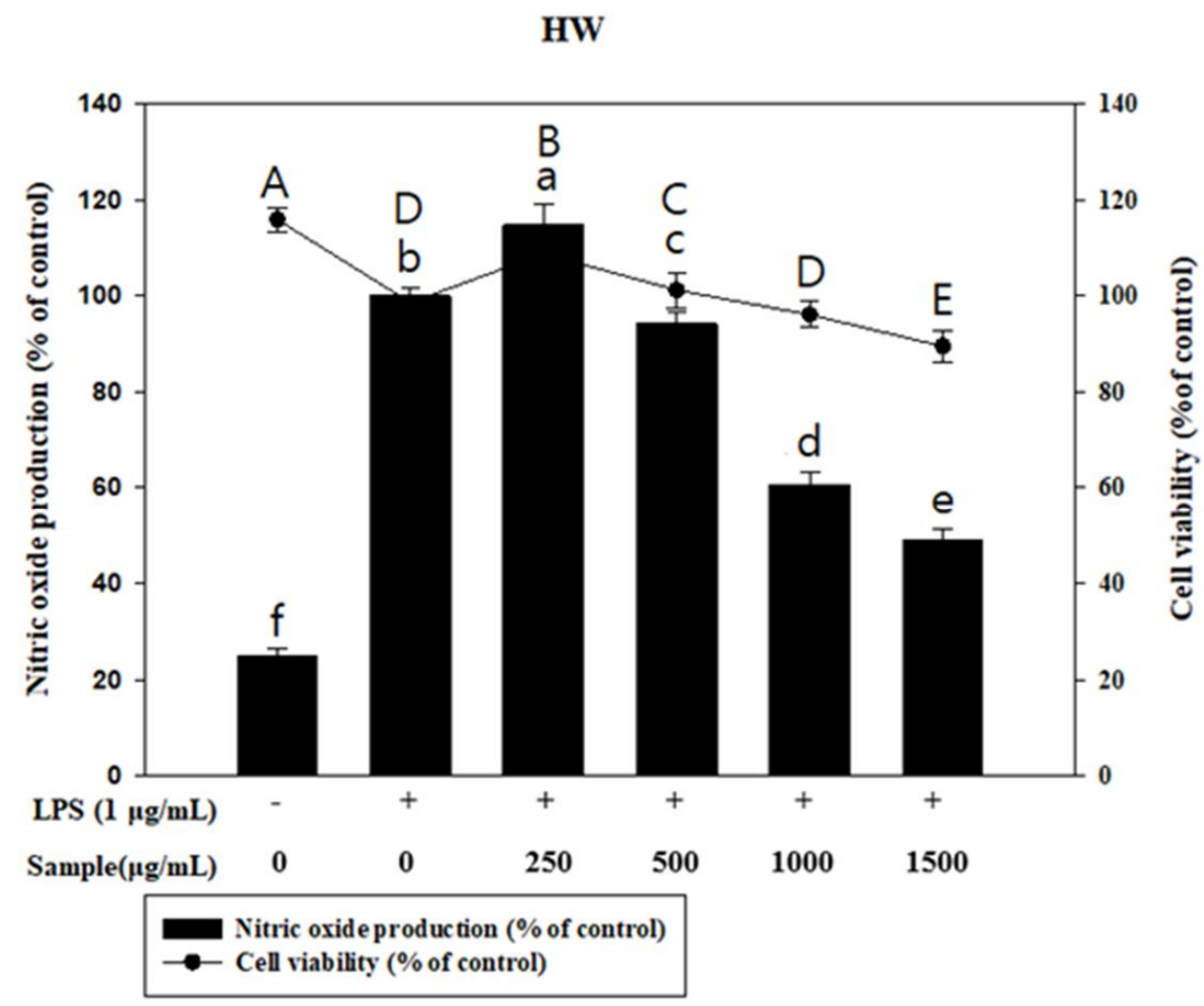

Figure 1. Effect of HW extract on cell viability and nitric oxide production in LPS-stimulated RAW 264.7 cells. Raw 264.7 cell were incubated with 250, 500, 1000 and $1500 \mathrm{ug} / \mathrm{mL}$ of $\mathrm{HW}$ extract for $1 \mathrm{~h}$, and then incubated with $L P S(1 \mu \mathrm{g} / \mathrm{mL})$ for $24 \mathrm{~h}$. The data expressed as a mean $\pm S D(n=4)$. Symbols or bars having the same letter are not significantly different at the 0.05

level. Uppercase letters show difference between symbols, while lowercase letters show difference between bars 
In the $70 \%$ EtOH extract, NO production was significantly increased in the LPS only treatment (LPS + , Sample $0 \mu \mathrm{g} / \mathrm{mL}$ ) compared to the control (LPS -, Sample $0 \mu \mathrm{g} / \mathrm{mL}$ ). However, EtOH extracts treated with 500,1000 , and $1500 \mu \mathrm{g} / \mathrm{mL}$ showed that $\mathrm{NO}$ production decreased (Fig. 2). Therefore, EtOH extract appears to have antiinflammatory effect like HW treatment and its effects are considered to be stronger than HW extract. The cell viability was significantly higher in the $50 \mu \mathrm{g} / \mathrm{mL}$ to $200 \mu \mathrm{g} / \mathrm{mL}$ treatment groups, and these results are showing alleviated toxicity at this concentration. And the highest concentration $(500 \mu \mathrm{g} / \mathrm{mL})$ did not show any significant difference with control. Therefore, this suggests that $H$. radicata extract induces cell proliferation by minimizing the effect of cytotoxicity. As a result, the $H$. radicata extract has not been shown to be toxic to the cell. Rather, in some treatments, it can protect cells by reducing the harmful effects on cells. And the $H$. radicata extract can be regarded as a function of inhibiting the generation of NO in high concentrations of extracts. In other words, $H$. radicata extract has a function of anti-inflammatory effect.

\section{EtOH}

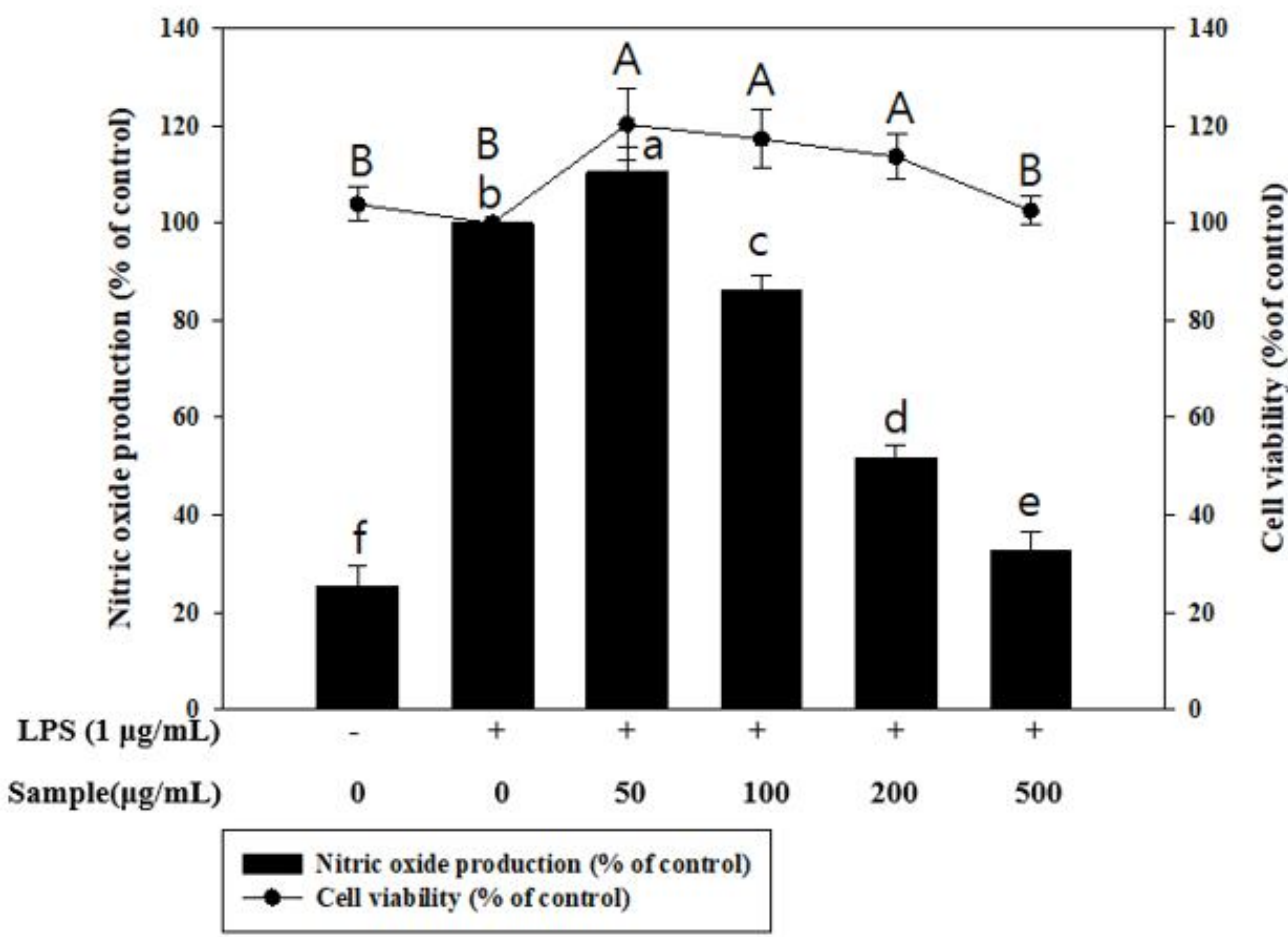

Figure 2. Effect of EtOH extract on cell viability and nitric oxide production in LPS-stimulated RAW 264.7 cells. Raw 264.7 cell were incubated with 50, 100, 200 and $500 \mathrm{ug} / \mathrm{mL}$ of EtOH extract for $1 \mathrm{~h}$, and then incubated with LPS $(1 \mu \mathrm{g} / \mathrm{mL})$ for $24 \mathrm{~h}$. The data expressed as a mean $\pm S D(n=4)$. Symbols or bars having the same letter are not significantly different at the 0.05

level. Uppercase letters show difference between symbols, while lowercase letters show difference between bars

\section{HPLC}

Since the extracts of $H$. radicata have shown some effects, HPLC analysis was expected to detect a certain level of natural products. However, only 1-Trans-Cinnamic 
acid was detected in the detection of phenolic compounds using 12 commonly used standards (Fig. 3). This suggests that the substances showing the function of the above results are slightly different from those of other plants, and $H$. radicata extracts are likely to contain new natural products rather than general ones. This shows that it is possible to obtain unusual natural products through a detailed analysis of this species in the future.

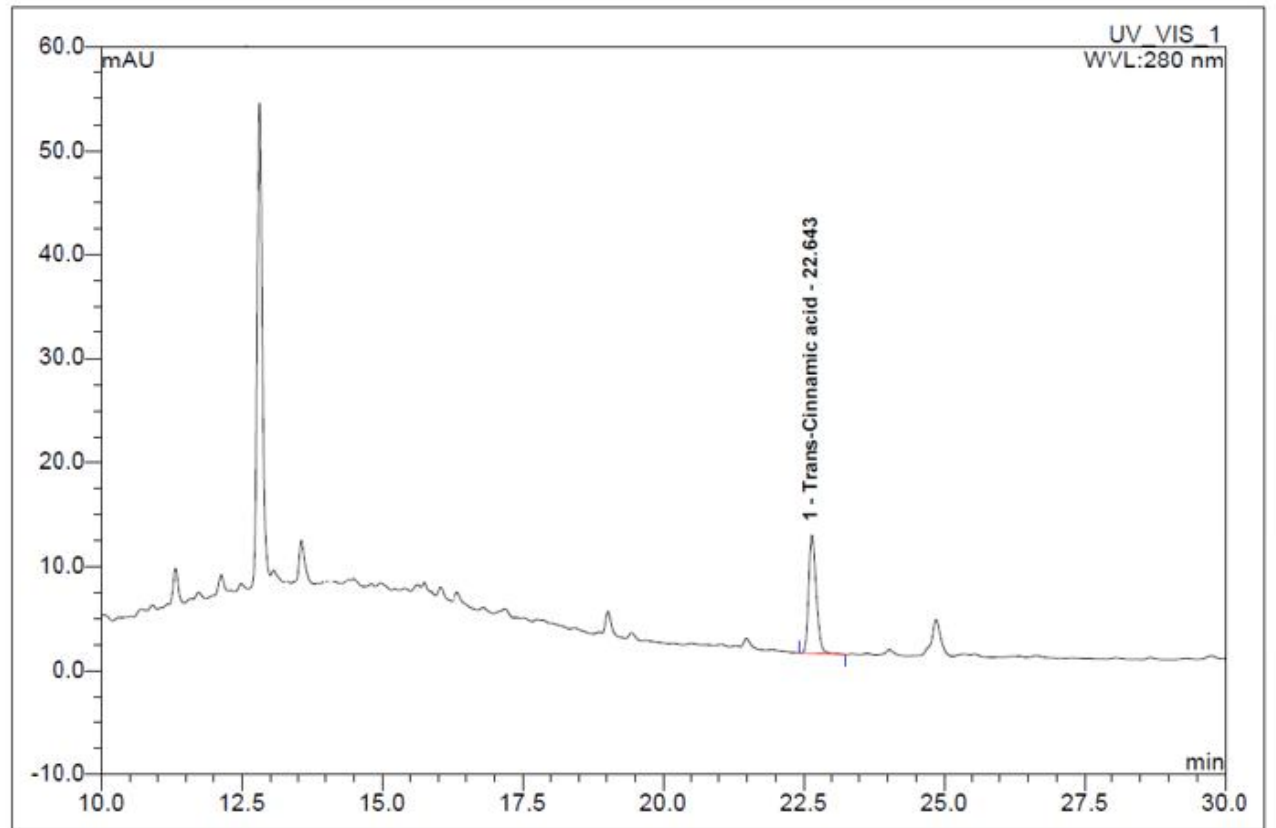

\begin{tabular}{|c|ccccccc|}
\hline No. & $\begin{array}{c}\text { Ret.Time } \\
\mathrm{min}\end{array}$ & Peak Name & $\begin{array}{c}\text { Height } \\
\mathrm{mAU}\end{array}$ & $\begin{array}{c}\text { Area } \\
\mathrm{mAU} \text { min }\end{array}$ & $\begin{array}{c}\text { Rel.Area } \\
\%\end{array}$ & $\begin{array}{c}\text { Amount } \\
\mathrm{mg} / \mathrm{L}\end{array}$ & Type \\
\hline 1 & 22.64 & Trans-Cinnamic acid & 11.391 & 1.769 & 100.00 & 1.034 & $\mathrm{BMB}$ \\
\hline Total: & & & 11.391 & 1.769 & 100.00 & 1.034 & \\
\hline
\end{tabular}

Figure 3. High performance liquid chromatography (HPLC) result of $H W$ extract

\section{Conclusion}

$H$. radicata has been reported as an invasive alien species that has been degrading ecosystem functions as a result of environmental damage, resulting in the extinction of native species and ultimately ecosystem diversity. However, despite the fact that it has been designated as a dangerous species, there is no effective way to prevent it from spreading. In Jeju Island, frequent mowing is used for environmental management of $H$. radicata, but still the species are dominating the island. It implies that we need a better engineering solution of management of $H$. radicata. Therefore, this study aims to contribute to the utilization of invasive alien species and resource management, and to some extent to prevent diffusion, by exploring the possibility of using $H$. radicata, an invasive alien species already introduced in Korea. All results show that $H$. radicata can be used for natural antioxidants and anti-inflammatory effects. Further researches could find correlation between environmental factors (soil, climate, species composition etc.) and medicinal effects of $H$. radicata and molecular reactions such as expression of Nuclear factor-kappa B. When the researches on effect of $H$. radicata are discovered more, the utilization of this species will be increased and the environmentally friendly 
public participation management will be possible due to the increase of the collection. As some medicinal or gardening herbs such as Panax ginseng (Park and Park, 2007), Hanabusaya asiatica (Park et al., 2013), Saccolabium japonicum (Jung et al., 2012) are endangered because it is being overharvested (Sangwon and Seonyeong, 2005), same effects can help to reduce $H$. radicata by increased usage. As harvesting wild vegetables are the common act in local (Hwang, 1991), this management mechanism is worthy to study. Therefore, we believed that it can be contributed to the prevention of diffusion of $H$. radicata to some degree when functions of $H$. radicata are discovered and be known to the public. In addition, it is meaningful that we have attempted to find an ecological approach (management through utilization) through utilization methods of alien species that has been spread widely in Korea.

\section{REFERENCES}

[1] Blois, M. S. (1958): Antioxidant determinations by the use of a stable free radical. Nature 181: 1199.

[2] Bradford, M. M. (1976): A rapid and sensitive method for the quantitation of microgram quantities of protein utilizing the principle of protein-dye binding. - Analytical Biochemistry 72: 248-254.

[3] Grassmann, J., Hippeli, S., Elstner, E. F. (2002): Plant's defence and its benefits for animals and medicine: role of phenolics and terpenoids in avoiding oxygen stress. - Plant Physiology and Biochemistry 40: 471-478.

[4] Griess, P. (1879): Bemerkungen zu der Abhandlung der HH. Weselsky und Benedikt „Ueber einige Azoverbindungen”. - Berichte der deutschen chemischen Gesellschaft 12: 426-428.

[5] Hwang, E. H. (1991): A survey on availability of wild vegetables. - The Korean Society of Food Science and Nutrition 20: 440-446.

[6] Hyun, J. O., Na, H. R., Kim, Y., Han, B. (2018): Floristic study of Aphaedo Island in Shinan-gun, Jeollanam-do, Korea. - Korean Journal of Plant Taxonomy 48: 65-99.

[7] Jaramillo, M. E., Gonz, L., Cornejo, M., Dorantes, L., Gutierrez, G. F., Hernandez, H. (2003): Effect of thermal treatment on the antioxidant activity and content of carotenoids and phenolic compounds of cactus pear cladodes (Opuntia ficus-indica). - Food Science and Technology International 9: 271-278.

[8] Jung, J., Lee, H., Jo, Y., Lee, B. (2012): Genetic diversity for restoration of Dendrobium moniliforme (L.) Sw. and Saccolabium japonicus Makino (Orchidaceae). - Korean Society of Forest Science 2012: 1112-1113.

[9] Khalaf, N. A., Shakya, A. K., Alothman, A., Elagbar, Z., Farah, H. (2008): Antioxidant activity of some common plants. - Turkish Journal of Biology 32: 51-55.

[10] Kim, C., Koh, J., Kang, Y., Moon, M., Lim, E., Kim, H. (2006): Scheme to classify invasive alien plants for natural ecosystem management in Jeju Island. - Korean Society of Forest Science 2006: 154-156.

[11] Ko, H., Eom, T., Song, S., Jo, G., Kim, J. (2017): Tyrosinase and alpha-glucosidase inhibitory activities and antioxidant effects of extracts from different parts of Hypochaeris radicata. - Korean Journal of Medicinal Crop Science 25(3): 139-145.

[12] Li, W., Luo, J., Tian, X., Chow, W. S., Sun, Z., Zhang, T., Peng, S., Peng, C. (2015): A new strategy for controlling invasive weeds: selecting valuable native plants to defeat them. - Scientific Reports 5: 11004.

[13] Maema, L. P., Potgieter, M., Mahlo, S. M. (2016): Invasive alien plant species used for the treatment of various diseases in Limpopo Province, South Africa. - African Journal of Traditional, Complementary and Alternative Medicines 13: 223-231. 
[14] Park, H., Park, A. (2007): Research on mountain ginseng. - The Korean Society of Ginseng 2007: 311-320.

[15] Park, S., Kim, H., Chang, J. (2013): Assessing Red List categories to a Korean endangered species based on IUCN criteria. Hanabusaya asiatica (Nakai) Nakai. - Korean J. Pl. Taxon. 43: 128-138.

[16] Peskin, A. V., Winterbourn, C. C. (2000): A microtiter plate assay for superoxide dismutase using a water-soluble tetrazolium salt (WST-1). - Clinica Chimica Acta 293: 157-166.

[17] Rafat, A., Philip, K., Muniandy, S. (2010): Antioxidant potential and phenolic content of ethanolic extract of selected Malaysian plants. - Research Journal of Biotechnology 5: 1.

[18] Ryu, T. B., Kim, M. J., Lee, C. W., Kim, D. K., Choi, D. H., Lee, H., Jeong, H. R., Lee, D. H., Kim, N. Y. (2017): Distribution characteristic of invasive alien plants in Jeju Island. - Journal of Ecology and Environment 41: 24.

[19] Samways, M. J., Caldwell, P., Osborn, R. (1996): Ground-living invertebrate assemblages in native, planted and invasive vegetation in South Africa. - Agriculture, Ecosystems \& Environment 59: 19-32.

[20] Sangwon, B., Seonyeong, A. (2005): A study on the evaluation method of endangered animals and plants species in the wild. - Korea Environment Institute 2005: 1-350.

[21] Scalbert, A., Manach, C., Morand, C., Rmsy, C., Jim, L. (2005): Dietary polyphenols and the prevention of diseases. - Critical Reviews in Food Science and Nutrition 45: 287-306.

[22] Senguttuvan, J., Paulsamy, S., Karthika, K. (2014): Phytochemical analysis and evaluation of leaf and root parts of the medicinal herb, Hypochaeris radicata L. for in vitro antioxidant activities. - Asian Pacific Journal of Tropical Biomedicine 4: S359S367.

[23] Song, U., Shin, M., Lee, G., Roh, J., Kim, Y., Lee, E. J. (2013): Functional analysis of $\mathrm{TiO} 2$ nanoparticle toxicity in three plant species. - Biological Trace Element Research 155: 93-103.

[24] Yang, E. J., Ham, Y. M., Lee, W. J., Lee, N. H., Hyun, C. G. (2013): Anti-inflammatory effects of apo-9'-fucoxanthinone from the brown alga, Sargassum muticum. - DARU Journal of Pharmaceutical Sciences 21: 62.

[25] Zhu, K. X., Lian, C. X., Guo, X. N., Peng, W., Zhou, H. M. (2011): Antioxidant activities and total phenolic contents of various extracts from defatted wheat germ. - Food Chemistry 126: 1122-1126. 